that the slave holders have lost the power of feeding themselves; but this is not unexampled in human affairs. Surely many a fine lady might starve outright in a place with no provender but live fowls and unthreshed wheat and water, no utensils but dry sticks and a few stones. Yet we know that savages of far lower wit could kill and pluck the fowls and get fire, spit and roast them, crush the wheat between the stones and make a damper cook it in the embers. This is a case of the loss of the power of self help by peculiar education, and if we admit this explanation for the fine lady we have no right to reject it for the slave holding ant.

I am aware that I have not dealt exhaustively with the whole question of social insects. There are lots of cruxes in their manners and customs, and especially in the manifold forms that occur in one and the same species. Why, for instance, worse food and a narrower cell should make a fertilized bee's egg become a sterile worker instead of a queen, no one knows; and the problems presented among ants are far more difficult and complicated. But it is as well to take stock frequently of our speculations, and to place our certain realized assets to the credit side, even though we have to keep most of our accounts open indefinitely. QUEEN'S COLLEGE, CORK. Marcus Hartog.

\section{THE PROPER SCIENTIFIC NAME FOR BREWER'S MOLE.}

There are three species of moles in the Eastern States, the Star-nosed mole, Condylura cristata, the common or Shrew mole, Scalops aquaticus, and a third less familiar species known as Brewer's mole, or the Hairy-tailed mole. It is to this last species that my remarks relate. It was described by Bachman in 1842 in the Boston Journal of Natural History (vol. 4, page 32) under the name of Scalops breweri, and was cited under that designation until 1879, when Dr. Coues proposed to change the specific name to americanus.' This proposition was based on the fact that in Harlan's Fauna Americana, published in 1825, the name 'Talpa americana, black mole, Bartram's manuscript notes,' occurs in synonymy at the head of a description which Dr. Coues thought might be in part, at least, applicable to the species under consideration.

I find, however, that this is a literal translation of Desmarest's description of the European mole, Talpa europoca, with no additions whatever, and no other alteration than the omission of a word or sentence here and there. It is evident, therefore, that Harlan included nothing from Bartram's manuscript, whatever it may have contained, and that the name Talpa americana has no validity.

It will be necessary to return to the specific name breweri. I recently separated Brewer's mole as the representative of a distinct genus, which I called Parascalops. If this distinction be accepted, the proper name of the species will be Parascalops breweri (Bachman).

\section{U. S. National Museum.}

Frederick W. True.

\section{THE AMERICAN FOLK-LORE SOCIETY.}

The annual meeting of the Society was held at the Columbian University, Washington, December 27th and 28th. Owing to a death in his family, the President, Dr. Alcee Fortier, of Louisiana, was prevented from attending.

The Secretary, Mr. W. W. Newell, submitted a report in which he detailed the publications of the Society for the year. These included two volumes of 'Folk Tales of Angola,' prepared by Heli Chatelain, late United States commercial agent at Loanda, West Africa, and papers by various wellknown authors as follows: 'Notes on the folk-lore of the mountain whites of the Alleghanies,' J. Hampton Porter ; 'Three 
epitaphs of the seventeenth century,'Sarah A. P. Andrews; 'Popular medicine, customs and superstitions of the Rio Grande,' Capt. John G. Bourke ; 'Plantation courtship,' Frank D. Banks ; ' Retrospect of the folk-lore of the Columbian Exposition,' Stewart Culin ; 'Eskimo tales and songs,' Franz Boaz; 'Popular American Plant Names,' Fannie D. Bergen.

A large number of papers were read before the Society and discussed by the members present. The first was by Dr. Washington Matthews, entitled 'A Navaho Myth,' which related in detail one of the sacred legends of the tribe.

Capt. R. R. Moten then read a paper on 'Negro folk-songs,' in which he spoke of natural musical tendencies of the colored race and reviewed a number of the old songs of the South before the war. Negro music, he said, might be divided into three kinds, that rendered while working, a different kind for idle hours, and a third and more dignified sort used for worship. Capt. Moten said the general public had but little idea of the old negro music, and that many of the so-called negro songs rendered by white men in minstrel performances were abortions. There were some old familiar melodies, however, which were true to nature, and full of inspiration.

A quartet of colored men was present, and sang a number of negro songs illustrating the points brought out by Capt. Moten.

Several speakers dwelt upon the important question of the diffusion of folk-tales and the explanation of striking similarities found in localities widely apart. Mr. W. W. Newell was inclined to explain such by theories of transmission; while Major J. W. Powell and Dr. D. G. Brinton, both of whom had papers on closely related topics, leaned toward the 'anthropologic' explanation, which regards those similarities as the outgrowth of the unity of human psychological nature and methods.
Dr. J. W. Fewkes gave a detailed description of the figures in the ancient Maya manuscript known as the ' Cortesian Codex.' Other papers presented were: 'Kwapa folk-lore,' Dr. J. Owen Dorsey ; 'Korean Children's games,' Stewart Culin ; 'Burial and holiday customs and beliefs of the Irish peasantry,' Mrs. Fanny D. Bergen ; 'Bibliography of the folk-lore of Peru,' Dr. Geo. A. Dorsey ; 'Mental development as illustrated by folk-lore,' Mrs. Helen Douglass ; The game of goose with examples from England, Holland, Germany and Italy,' Dr. H. Carrington Bolton ; 'The Swastika,' Dr. Thomas Wilson; 'Folk-food of New Mexico,' Capt. John G. Bourke, U. S. A.; 'Opportunities of ethnological investigation on the eastern coast of Yucatan,' Marshall H. Saville; 'Two Ojibway tales,' Homer H. Kidder.

The officers elected for the ensuing year were: President, Dr. Washington Matthews ; Vice Presidents, Rev. J. Owen Dorsey, Captain John G. Bourke, U. S. A.; Permanent Secretary, William Wells $\mathrm{Ne}-$ well, Cambridge, Mass.; Corresponding Secretary, J. Walter Fewkes, Boston, Mass.; Treasurer, John H. Hinton, New York, N. Y.; Curator, Stewart Culin, Philadelphia, $\mathrm{Pa}$.

D. G. Brinton.

University of Pennsylyania.

SCIENTIFIC LITERATURE.

Les oscillations électriques.-H. Poincaré, Membre de l'Institut. Paris, George Carré, 1894.

This work contains, briefly stated, a clear mathematical discussion of the general features of the Faraday-Maxwell electromagnetic theory in Hertzian form, and of those special problems bearing upon this theory which are of particular interest to the experimentalist. The mathematical solution of these problems is compared carefully with the results obtained, principally by the experiments of Hertz and of other investiga- 